American Association for the Advancement of Science meeting in Houston, Texas.

Reports by David Dickson

\title{
AAAS president calls for closer university/industry links
}

WITH US industry under pressure to remain competitive, and universities facing problems in securing research support from conventional sources, the time has come for a closer relationship between the two, according to $\mathrm{Dr}$ Edward David, president of the American Association for the Advancement of Science.

Close links between the industrial and academic communities could help to preserve important features of the research system: a pluralism of funding sources, leading to greater local autonomy in the conduct of research and development programmes; a more competitive environment, based on technical excellence; and a dependence on "high achievers" able

\section{US to brief scientists on human rights}

THE US State Department is preparing briefing materials for scientists and others who participate in official exchanges, describing the goals and objectives of the US human rights policy, and responding to questions about the legality and safety of activities in defence of colleagues abroad.

Mrs Roberta Cohen, of the Department's Bureau of Human Rights and Humanitarian Affairs, told a session on international freedom and responsibility that US Government agencies and representatives had been instructed not to discourage or prohibit exchange participants from contacting private Soviet citizens. "We in the Bureau of Human Rights take it as an obligation of the Government to correct any wrong impression created that it is seeking to discourage scientists on exchange programmes from efforts to defend foreign colleagues," she said.

The Government asked only that contacts of potential sensitivity, particularly in tense periods, be discussed in advance with Administration officials, "in order to ensure that American scientists involved have full information assessing the potential risks".

A blanket halt to exchanges had distinct disadvantages, ranging from a reduction in the exchange of ideas to raising the spectre of Government interference. Boycotts of meetings were not likely to be as productive as participating and expressing human rights concerns, she said. to provide scientific leadership.

If basic research was defined not as research carried out with no particular goal in mind, but rather as any research leading to a greater understanding of natural and social processes, regardless of the motive, then the amount of such research being carried out by industry was larger than current definitions indicated. Industry had also widened its research interests beyond just improving the technology of production lines. "Today there is a much broader point of view, ranging from the sociology of customers, to research on the $R \& D$ process itself." Industrial research was increasingly using the basic research paradigm in forwarding its function, and it would not be incompatible to couple this directly with academic interests.

In the $1950 \mathrm{~s}$ and $1960 \mathrm{~s}$, industry support for university research had been primarily philanthropic in nature. Now a number of companies were exploring ways of setting up long-term cooperative arrangements with universities. "Ten years from now I expect to see a vigorous community of industrial/academic scientists, with academics providing the ideas and industry providing the vehicle for their commercialisation. This will certainly be an improvement on the situation that we have now. And it will be more in keeping with the situation facing both sides in the 1980s."

\section{Rethink for research funding}

A LARGE proportion of federal funds for university research should be distributed to institutions on a "formula" basis calculated on proven capability and productivity. Such a "deregulated and decentralised" system for research grants would avoid much of the unnecessary work involved in the current grant - proposal/peer - review process, Professor Rustum Roy, chairman of the science, technology and society programme at Pennsylvania State University, told a session on federal research and development funding. He also suggested a three-year national commission to set national priorities in research and development, with a strong input from the scientific and engineering community.

Professor Roy said existing research and development mechanisms were designed for the "golden age" of science in the 1950s and early 1960s, but were no longer appropriate. The new social setting for $R$ and $D$ included: public recognition of the "ambivalence" of science and technology, rather than seeing either as solely beneficial; widening gap between science and the public; a recognition that there is no simple relationship between support for basic science and a healthy economy; and the fact that the system had not led to maximum innovation in the industrial sector

The problem lay not so much in getting more money for basic science"possibly the least important question" -as in designing a more efficient system for the disbursal of funds, where radical changes could produce a major increase in productivity.

A clearly stated rationale for the support of science was also needed. Most important would be contributions to nationally-defined objectives such as defence, health and energy; then would follow science for graduate education, science for state, community and local needs, and finally "science for science's sake”. Congressman George E. Brown, a leading member of the House of Representatives Committee on Science and Technology, pleaded for a more sophisticated strategic planning operation for the national scientific effort.

"It is impossible to develop a new rationale for the support of science and better mechanisms for carrying this out without a strong and welldefined central planning authority in the scientific sphere," he said. Some members of Congress had hoped that this role would be played by the President's Office of Science and Technology Policy when it was reestablished in 1976. However, many of the policy and planning tasks envisioned for OSTP had gone to other offices further from the executive centre.

Another need was to develop mutually reinforcing networks of research institutions. "The capabilities of various federal, state and local laboratories must be better linked, both in terms of facilities and people. Only when we have taken such moves can we persuade the public and Congress that critical gaps in research remain and are in need of support." 